\title{
The Javanese Panji Story: its transformation and dissemination into the performing arts in Southeast Asia
}

\author{
${ }^{\circledR}$ Triyono Bramantyo ${ }^{1}$, Susan Hung ${ }^{2}$ \\ ${ }^{1}$ Institut Seni Indonesia Yogyakarta, Indonesia \\ ${ }^{2}$ Graduate Department of Ethnomusicology, \\ Tainan National University of Fine Arts, Taiwan
}

Received: September 17, 2017. Revised: November 24, 2017. Accepted: December 4, 2017

\begin{abstract}
This paper studies descriptively several versions of Javanese Panji Story with its transformation and dissemination into the performing arts found in Southeast Asia. Accordingly, there are versions varied not only regarding its stories, locations, events, and the style of its narratives but also the flow of the stories. So many other versions have not been described here in this paper just to imagine how this 13th century Javanese literature has turned out to become so many versions. Moreover, the story has spread out not only in Indonesia but also throughout the Southeast Asian archipelago. The study found that authenticity is not the concern because the original version of the Panji Story was not existed and thus texts can be in so many forms. However, what was overwhelming is that the story had been transformed into so many genres of performing arts in Southeast Asia, such as in Indonesia, Thailand, Cambodia and Myanmar, the former state of Burma. The study found that the performing styles of Panji or Inou in Indonesia, Thailand, Cambodia, and Myanmar shared the same styles as typical classical dance of Royal Palace that performed high standards of performances such as glorifying model of costumes and accompanied by aesthetically qualified Royal Palace Music Ensembles.
\end{abstract}

Keywords: Panji Story; transformation; performing arts

How to Cite: Bramantyo, T. \& Hung, S. (2017). The Javanese Panji Story: its transformation and dissemination into the performing arts in Southeast Asia. Harmonia: Journal of Arts Research And Education, 17(2), 113-119. doi:http://dx.doi. org/10.15294/harmonia.v17i2.11539

\section{INTRODUCTION}

A monument that was erected during the reign of King Dyah Balitung of Central Java dating from approximately 907 CE (Ministry of Education and Culture, (1983-1984)) provides the oldest written record of a wayang performance, which was based on the Mahabharata epic tale.

The Ramayana was also an essential source in the development of the performing arts in the early civilization of Java.
The history of the Ramayana dates back to approximately the 5 th- 4 th century BCE. It is believed that the original version of the story is Valmiki's Ramayana. Some cultural evidence suggests that the Ramayana predates the Mahabharata. Regardless of which tale appeared first, these two important Indian literary works have been adapted to many forms in Javanese performing arts and those of the rest of Southeast Asia. They are Javanese Ramayana, the Javanese Mahabharata, the Balinese Ra-

\footnotetext{
${ }^{\square}$ Corresponding author: Jl. Parangtritis Km 6,5, Sewon, Bantul, Panggungharjo, Yogyakarta, 55188

E-mail: t_bramantyo@yahoo.com
} 
mayana, the Phra Lak Phra Lam of Laos, the Hikayat Seri Rama of Malaysia, the Ramakien of Thailand, the Yama Zatdaw of Myanmar, etc. (Bramantyo, 2015).

Alongside the Ramayana and the Mahabharata, there is a local Javanese cycle called the Story of Panji, which, according to C.C. Berg's work Inleiding tot de Studie van Het Oud-Javaansch (1928), was disseminated in the year of Pamalayu (1277 CE). Purbatjaraka, an expert on the Panji cycles, writes: "[...] the writing of the early Panji story was during the supremacy of the Majapahit Kingdom" (Purbatjaraka, 1968). The Story of Panji subsequently spread throughout the Southeast Asian region, including present-day Malaysia, Thailand, Cambodia, Myanmar, and Laos, and has been adapted to a variety of performing arts.

There are different versions and episodes of the Panji cycles. The main story, however, is about the romance between Prince Panji and Princess Kirana, a tragic tale of love, full of adventures and challenges that sometimes concludes with a happy ending. This paper is a descriptive study of versions that can be found in Purbatjaraka's book Tjerita Panji Dalam Perbandingan (1968) and in R.A. Kosasih's Pandji Semirang (1978), with some additions taken from the videos of Inao Festival held by Spafa, Bangkok, Thailand, 2-6 March 2013.

It is possible that the Mahabharata may have influenced some stories in the Panji cycles. In his genealogy entitled Pustaka Radja Mada, the Surakartan poet Ranggawarsito writes: "the Javanese Kings, including Panji, are considered the descendants of the Pandavas of the Mahabharata" (Brandon, 1970).

This empirical research aims to explore the fact that this classic Javanese roman of $13^{\text {th }}$ century has been widely known in Southeast Asia of that period and has been adopted to become classical performing arts in several kingdoms in the region. It can be used as a coincidence of how this ancient roman cycle of Java has gained so much popularity as popular as Indian Ra- mayana and Mahabharata stories.

The transformation of the Panji cycle into classical performing arts (mostly dance) in Southeast Asia can be traced back recently. We thank the SEAMEO-SPAFA (The Southeast Asian Ministers of Education Organization Regional Centre for Archeology and Fine Arts) for the initiative and to host the Panji/Inao Festival held in Bangkok, Thailand, 2-6 March 2013.

In this paper, the main characters of the story are Prince Panji Kertapati and his fiancée Princess Dewi Sekartaji or Galuh Candrakirana. In Thailand and Cambodia, name of Panji becomes Inou, and Dewi Sekartaji becomes Bossaba or Bussaba (accordingly it is come from the word 'puspa' in Javanese language which is mean 'flower,' since a beautiful lady usually personified as beautiful as a 'flower'). In Myanmar, Inou become E-Naung and Bosabba becomes Busba. The names of kingdoms in Java where this story initially comes from can be recognized such as Kahuripan dan Daha. Some other kingdom names are not explicit, but probably they are corrupted names of Javanese language or perhaps some common local names of local kingdoms.

In studying the transformation and dissemination of the Panji Story, for the writer, it is so much a wonder to realize how the unwritten Javanese Romance of $13^{\text {th }}$ century can be adopted and be adapted to become 'their' own arts. It seems there is no conflict of 'self and Other' dichotomy in sort of the legacy of cultural influences (Payne \& Barbera, 2010), in this process of transmission from the beginning to the present day.

\section{METHOD}

This study employs analytic history methods found in cultural studies. In a limitation of readily available related references, the writer has borrowed the method of analytic history of cultural studies focuses primarily upon theoretical and methodological dynamic (Tudor, 1999). The implementation of this approach, in 
this case, is that the writer studies some documents that have been carefully considered to see the various types and genres of the stories. Meanwhile, the videos of the performance of Inou/Panji from Cambodia, Thailand, and Myanmar, mostly available on Youtube uploaded by SPAFA (2013) have been selected to see the transformation of the story into the performing arts.

The problems of originality of the genres are not mentioned in this paper because it is so hard to identify the originality when it has been lost due to the social and political war that happen for such long time (in case of Cambodia and Myanmar). So, the videos were saw and analyzed the whole structures and the stories of the episodes. It was found that they are still very relevant to the main ideas of the Panji cycles. Thus, that means that the performances should then to be accepted as the new versions of the original Inou/ Panji episodes of the given countries.

Accordingly, unwritten folklore like the Panji Story is part of tradition, and it is dynamic. The study have found that in this process of sharing the tradition has helped the continuity of culture and the importance of time and repetition in tradition that implies a sense of continuity and of divided materials (Sims, 2005).

\section{RESULTS AND DISCUSSION}

Below is the results or the discussion about the research and they are in a form of descriptive. Therefore this research is descriptive one with some addition of critical comments. This research is also a preliminary study, and thus further examination and elaboration of the topics would be if necessary. The lack of bibliographies reliable in this research was caused by not so many of the documents related to the issues can be found in Indonesia.

It should be noted here the questions concerning the music for the performance of The Panji / Inao stories that might exist. They are (1) How the music transmitted to different place influences on the music? (2)
Is the music of various place influences the story? In answering those questions shortly, I would like to make my account based on the documents that did not explicitly described any music for the accompaniment at all. Firstly, there is no such typical Panji/Inou music accompaniment for the dances and dramas in Java and in Southeast Asian Inou Drama. Secondly, nor that the music of different place influences the story, for there is no such specific music accompaniment for the Panji/Inou Story.

Take for the example of the Javanese classical performance of Panji Story's episode that might used a gamelan ensemble of classical gendhing repertories that already existed and be selected and adapted to accompany the performance. The selection and adoption of the gendhing repertories normally follows the dynamic flows of the actions on the stage.

For Inou performance from Thailand, they usually used the Pi Phat Mai Nuam ensemble, a typical classical repertories for court ceremonies use. Accordingly, the Pi Phat Mai Nuam ensemble was created during the reign of King Rama V by Chao Phraya Thewat Wongwiwat. Wongwiwat not only rearranged the entire Pi Phat ensemble as the accompaniment for dance and drama but also replaced Khlui Phiang $O$, which is a medium fipple flute, and the Khlui Lip, which is a small fipple flute for Pi Nai and Pi Nok (a soprano and sopranino oboe). In addition, a So $U$ was included, which is an alto fiddle and replaced the hard mallets with full ones. The ensemble usually performs with the Thai traditional mask dance, so-called Khon (Wikipedia. Retrieved on 10 August 2017).

Cambodian performance of Inou Drama uses the Pinpeat ensemble. The pinpeat orchestra or musical ensemble performs the ceremonial music of the royal courts and temples of Cambodia. The orchestra consists of approximately nine or ten instruments, mainly wind and percussion (including several varieties of $x y-$ lophone and drums.

As music for the E-Naung performance from Myanmar, it can be noted as 
follows. The basic idea of much of Burmese (now Myanmar) classical music is to create an "inner melody" like the one we found in the Indonesian Gamelan music. The impression when we are listening this melody is that it sounds like improvising all around and ornamentation notes play in such a way like the true "inner" melody that never heard by the audience. However, indeed, it functions as a core melody for all performers to improvise from. In other words, nobody plays it, but everyone knows it.

In describing the music produced by a traditional Burmese orchestra during the performance, it sounds that the music is so much playing in narrative ways. The instruments comprises of a set of gongs, finely tuned drums and an oboe-like instrument called nhai. Nhai looks similar to that of a Javanese slompret (trumpet). Accordingly, its pieces sound richly theatrical. Melodies start slowly then very often it is suddenly frantic ahead, then pause and turn sideways in ways that merrily defy prediction. It should be noted here one of the oldest genres, thakyinkan, is used during offerings to the Buddha. Some of these particular song forms were later matched with particular dances and song structures derived from the Thai Ramayana and Inao dramas called Yodaya (Young, 2015).

Prelude to the Panji Stories: "The Book of Smaradahana'

This book, entitled Kakawin Smaradahana, was written by Mpu Dharmaja in the early 12th century CE and was later incorporated as a prelude to the Panji tales. It describes that King Kamesjwara (Kamajaya) of the Court of Kediri reigned from 1037 to 1052 (1115 - $1130 \mathrm{CE})$ and that he is the third incarnation of Batara Kamadjaja. Kamesjwara's wife, SriKiranaratu, also known as Dewi Kamaratih, was a princess of the Court of Djenggala.

The story tells that both husband and wife have disappeared from Svargaloka (heavenly earth) and were burnt by the fire of Shiva, lord of destruction. The spirits of Kamajaya and Kamaratih fell to the earth and were incarnated several times as mortal human beings. Accordingly, the main characters of the Panji cycles are Prince Panji and Princess Kirana, the notable incarnations of Kamajaya and Kamaratih on earth (Purbatjaraka \& Hadidjaja, 1952).

\section{The Panji Story of Cambodia}

According to Purbatjaraka, this Khmer Eynao story is of Indian origin. But, this assumption is not make sense because there is no coincidence of the name of Daha Kingdom both in Ramayana or Mahabharata. In this version, accordingly, that the king of Daha decides that his beautiful daughter, named Bossaba, will be engaged to his nephew, Eynao. However, he later marries the princess of another kingdom before he meeting his fiancée, the princess of Daha (Bramantyo, 2015).

One day, the Kingdom of Daha is attacked by neighboring kingdoms and sends a call for help. The king of Kuripan, Eynao's father, orders his son Eynao to lead his army to help the king of Daha. Eynao defeats the invaders, all of whom surrender and are requested to submit their loyalty to the king of Daha. Eynao receives a warm welcome by the king of Daha, his own uncle and all of the high-ranking officials. Bossaba does not want participate in the festivities thrown in her fiancé Eynao's honor because he broke her heart when he married another girl.

When Eynao sees Bossaba, he is mesmerized by her beauty and cannot contain himself. He then blames himself for marrying the other princess. Eynao cannot help wanting to attract Bossaba's attention, which he can hardly obtain. He asks his brother-in-law Sijatra to help him several times, but he does not succeed. In the end, Eynao is so upset that he wants to kill himself when he finds out that Bossaba wished to marry a prince from another kingdom named Charika.

His brother, Sangkha-Marita, tries to help him by kidnapping Bossaba and bringing her to a remote place in a cave that has already been decorated for Eynao and Bossaba's wedding. Still, Eynao does not 
manage to win her love and finally declares: "If you are certain of your decision to not accept me and if I am hopeless in begging for your affection, then I have no reason to be here. I will thus go far away across the mountains and jungles until I die, because I have promised myself that I would only return to my father's palace with you by my side, surrounded by your love, which to me is more precious than all of magnificence of the palace." (Purbatjaraka, 1968)

One day, Bossaba is alone in the cave to which Eynao took her when he kidnapped her. She has the chance to look around the cave, but suddenly, a whirlwind takes her to the palace of Pramotan. It was She meets her grandmother, Pattarac-cala, who says: "I am your first grandmother, and I condemn Eynao for two things. First, for refusing your hand in marriage and taking another lady as his wife, and secondly for kidnapping you. This young man has disappointed me, and thus he should be punished to what he has done. I will turn you into a man named Onacan, and you will be adopted as the king of Pramotan's son."

Eynao and two of his followers go searching for Bossaba's whereabouts. They reach the Kingdom of Sangvat-borey and introduce themselves with new names: Eynao as Panji, Sangkha-marita as Acharangvisangka and Vijada as Vorot-kenlong. Onacan (Bossaba's new name as a young man) keeps thinking of Eynao and sees in 'his' dream that Eynao has now become an ascetic somewhere to the east of 'his' new home. 'He' then asks for 'his' stepfather's permission to look for a future 'wife' for 'himself' and thus heads east where 'he' meets Panji and his followers. Panji says to Acharangvisangkha: "Keep an eye on this young man, he looks like Bossaba; it is impossible that the gods have changed her into a young man to look for us" (Purbatjataraka, 1968). Panji confirms that Onacan is Bossaba dressed as a man. As a result, Panji wants to stay there to be able to see Onacan everyday.

To shorten the story, one day Bossa- ba asks Acharang-visangkha to write and draw a story on the skin of a water buffalo. He draws the cave and the stories about Bossaba and Eynao on the skin. Upon seeing this, Bossaba wants to meet Eynao as soon as possible. Acharang then tells her that it was Eynao who asked him to draw and write these stories on the skin. Eynao is standing there listening to them at that very moment.

A surprised Bossaba runs to meet Eynao, but she falls unconscious. Eynao sprints to hug her and help her regain consciousness. They are finally reunited despite having been apart for ten years, separated by Pattarac-Cala who punished Panji because of his mistakes. As expected, this version concludes with a happy ending with the reunion of Panji/Eynao and Galuh Candrakirana/Princess Bossaba.

\section{Notes:}

Notes that this version mentions four kingdoms without giving the names of each king. Both Eynao and Bossaba serve the king of Kalang (Gagelang). Bossaba turns into a young man named Onacan and Eynao changes his identity to Acharang. Both experience great adventures and have to face so many challenges, but it all comes together in the end. In this version, both the kingdom of Singasari as well as the name of Panji did not specified, but Panji disguised as Eynao or Acharang.

In the recent performance of Pan $\mathrm{Yi}$ (Panji) Story at the Iano Festival in Bangkok, Thailand, the Cambodian Royal Ballet presented one of the episodes that told about the Bossaba (Princess Kirana) and her meeting with Pan Yi in a such short moment. Here is the story:

Khmer Classical Dance, also known as Cambodian Royal Ballet, is a highly stylized form of court dance drama. While the story of Panji, known as Inav in Khmer, is no longer performed today, some episodes were favored by the Kings of Cambodia between 1900 and 1940. It is believed that Queen Sisowath Kossomak Nearirath is responsible for redeveloping the Inav/ Bussa $\mathrm{Ba}$ performance in Khmer Classical 
Dance. However, since only a few episodes were created in this art form, it is impossible to know the whole Khmer version of this legend.

In this episode, Prince Siyatra is in the forest where he sees a peacock created by the god Indra. He and his retinues chase the peacock to the border of the territory of Kalaing. Disguised as Yarann, he serves the King of Kalaing with the help of General Pan Yi and his brother Sangka Mota, after which he is awarded a high title. Bosseba, whose original name is Kaen Long, and Yarann meet one day while she is visiting a garden. Upon seeing Yarann trying to court Bosseba, General Pan Yi becomes angry. A fight ensues between the both of them, but the King intervenes. Then, Yarann pulls out the kalaing kroeus (a small two-edged knife), which reveals to all his true identity: Prince Siyatra.

\section{The Panji Story of Thailand}

A synopsis written for the performance of an episode of Panji of Thailand described that this Thai classical dance, called Lakon Nai, is a court dance drama that is performed by an all-female troupe using elegant and graceful movements. This type of dance drama evolved according to royal tradition within the precincts of the palace. It is believed that Lakhon Nai was redeveloped under the patronage of King Rama II in the early 19th century. (Seameo-Spafa. (2013). "Program Notes" of the Panji/Inou Festival in Bangkok, Thailand.).

In the event of Inao/Panji Festival held by Spafa in Bangkok, Thailand, 2-6 March 2013, the troupe performed the episode entitled "Inao Exiting the Cave." This episode takes place after Inao and Bussaba have fallen in love and eloped. They are hiding in a cave, but Inao needs to leave her there to face the problems they have caused. Inao rides a horse to the Kingdom of Daha, accompanied by his retinues, rides a horse to the Kingdom of Daha (former Kingdom settled in Kediri, East Java, Indonesia) to explain his actions to the King.

\section{The Panji Story of Myanmar}

The information below has been taken from a synopsis of the performance of E-Naung Drama Troupe of the Ministry of Culture, Myanmar, performed during the Inao/Panji Festival 2013 in Bangkok, Thailand. The whole performance has 9 scenes with some names still related to the home of the story in Java, i.e., the kingdom of Kurepan (Kahuripan in Javanese) and the kingdom of Daha. In this Myanmar version, E-Naung is Inao or Prince Panji, and Busba is Princess Dewi Galuh Candra Kirana. Some other names are not related to Java of even Myanmar itself.

Scene 1: Indra, Lord of the celestials beings (in Hinduism), present the four-edged dagger thanhlyet to the Prince E-Naung in his cradle. Meanwhile, the parents and the royal families are discussing future wedding plans for the baby E-Naung.

Scene 2: E-Naung, now a man grown, is with the King of Kurepan and the King of Daha, whose daughter (Busba or Bussaba) has been betrothed (engaged to be married) to him since childhood. They are discussing the wedding plans when suddenly a call for military support reaches them from the King of Manra. The King of Kurepan answers this call by sending E-Naung to drive out the invading troops from seven kingdoms.

Scene 3: E-Naung reaches the Kingdom of Manra and defeats the kings from the seven kingdoms easily.

Scene 4: E-Naung meets the King of Manra's daughter, Princess Nan Kannaiya, who is celebrating the hair washing ceremony. It is love at the very first sight (please be remembered that Prince E-Naung or Prince Panji, despite having his superpower from God, is also typical a man who is passionate about women and has many lovers but only Busba or Princess Kirana is his real lover). So, E-Naung and Nan Kannaiya do not act on their feelings as ENaung has been promised to marry Busba.

Scene 5: This is the first challenge for E-Naung in this episode when after receiving a painted portrait of Busba, the Prince of Saraka asks the King of Daha 
for Busba's hand in Marriage. The King of Daha angry at E-Naung for not fulfilling his promise agrees to the request of the Prince of Saraka. Meanwhile, Wirasakan, son of the King of Panankunein, also asks for Busba's hand in marriage, threatening to wage war if his request is not granted. The King of Daha thus appeals to the King of Kurepan for help. Scene 6: The King of Kurepan answers the King of Daha's call for help by sending E-Naung to attack and defeat Wirasakan troops. Svece 7: Having successfully defeated the enemy, a ceremony is thrown in E-Naung honours, during which Princess Busba offers a flower garland to Prince E-Naung as sign of her love. Scene 8: E-Naung finds out that Busba is already engaged to the Prince of Saraka. This upsets him, after which his attendants burn down the wedding pavilion. Meanwhile, E-Naung disguises himself and elopes with Busba.

Scene 9: Prince E-Naung takes Princess Busba to the forest. When he removes his disguise, Busba recognizes him and rejoice.

\section{CONCLUSION}

The Panji Story is a roman cycle originated $13^{\text {th }}$ century of Java or earlier, even though the influence of imported roman of Indian Mahabharata or Ramayana is possible. The Panji story has transformed into so many folk performances as well as classical performing arts in Indonesia. Most of the genres are using the masks for the whole characters found in Panji stories' episodes.

The main characters of Panji story are Prince Panji Kertapati simply known as Panji and his fiancée namely Princess Dewi Sekartaji or Galuh Candrakirana. The Panji story still very popular in Java and some festivals are still be managed to run every year in several places.

The popularity of Panji/Inou story can be found not only in Indonesia but also in Southeast Asia countries such as in Thailand, Cambodia, Myanmar and Malaysia. What most remarkable is that the Panji story has transformed into so many kinds of genres of performing arts in Southeast Asia as well.

\section{REFERENCES}

Bramantyo, T. (2015). Panji Story: From Version to Version: Papers Presented at Bali Puppet Seminar 2013. Singapore: Partridge.

Brandon, J. R. (1970). On Thrones of Gold: Three Javanese Shadow Plays. Cambridge: Harvard University Press.

Kosasih, R. A. (1978). Pandji Semirang. Bandung: Penerbit Erlina.

Ministry of Education and Culture. (19831984). Project of Cultural Media.

Padmapuspita, Y. (1982). Panji Jayakusuma. Yogyakarta: Proyek Javanologi.

Payne, M. \& Barbera, J. R. (2010). A Dictionary of Cultural and Critical Theory. $2^{\text {nd }}$ Edition, West Sussex. UK: Blackwell Publising Ltd.

Purbatjaraka, R. M. N. (1968). Tjerita Panji Dalam Perbandingan. Jakarta: Penerbit PT Gunung Agung.

Sims, M. C. (2005). Living Folklore: An Introduction to the Study of People and Their Traditions. Utah: Utah State University Press.

Tudor, A. (1999). Theory and Method in Cultural Studies. California: SAGE Publications Inc.

Young, K. (2015). Music and Dance from Myanmar: Shwe Man Thabin Zat Pwe Program in Asia Society: Program Notes of April 10-11. 